\title{
Research on Urban Community Facilities Safety Governance-Based on the Overall Perspective
}

\author{
Yanping Liu' ${ }^{1}$ Zhixiang Yuan², Yong Wang ${ }^{3 *}$ \\ ${ }^{1}$ College of Economics and Management, Tianjin Chengjian University, Tianjin, China \\ ${ }^{2}$ Seismological Bureau of Shaanxi Province, Xi'an, China \\ ${ }^{3}$ College of Geology and Geomatics, Tianjin Chengjian University, Tianjin, China \\ Email: *liuxiawy@126.com
}

How to cite this paper: Liu, Y.P., Yuan, Z.X. and Wang, Y. (2017) Research on Urban Community Facilities Safety Governance-Based on the Overall Perspective. World Journal of Engineering and Technology, 5, 36-41.

https://doi.org/10.4236/wjet.2017.53B005

Received: March 22, 2017

Accepted: August 8, 2017

Published: August 11, 2017

\begin{abstract}
Community facilities accidents happen every year in many cities of China, which has been an important issue in academic circles. The purpose of this study is to suggest the direction of universal design for the prevention of community facilities accidents. In this paper, from the overall angle, the impact factors of the urban community service facilities safety were analyzed. Then, based on the integrated governance theory, from such aspects as engineering and non-engineering disaster reduction, the governance measures were explored.
\end{abstract}

\section{Keywords}

Community Facilities, Integrated Governance Theory

\section{Introduction}

A series of community facilities from various cities make public awareness of the importance of community facilities safety management. Community facilities are those buildings, works and land areas which are devoted to public or semi-public uses. They include a variety of public buildings to house the administrative, educational, cultural, recreational, health, safety and service needs; public works and utilities to provide water, power, heat, light, communications, sewage treatment, flood control, and transportation; and public open space for parks, playgrounds, malls, etc. [1]. The concept of facilities management in a community-based setting is derived from understanding the social value of community facilities and the management of community assets, which include people, buildings, voluntary groups, etc. [2]. By collecting and analyze the literature and document of FM in the community context, we found that the exist- 
ing research mainly focused on a segment or a type, and lacks attention to community facilities safety governance from the overall angle [3]-[15]. It is a must for us to analyze the factors that cause the urban community facilities safety accidents and to design the systematic governance strategy, which puts forward the importance of integrating all stakeholders work together in systematic governance within planning, design, construction, operation and maintenance dimensions in support of community public interests, and have integration management thought on community-based facilities in China.

\section{Factors Affecting Urban Community Facilities Security}

\subsection{External Factors}

1) Natural factors

Such factor as storm, Frost, earthquakes, ground subsidence, which can pose great impact on the urban community facilities. Take earthquake as example, it can bring about disturbance to surface or shallow ground facilities, and cause foundation settlement. Vibrations may cause the ground collapses, and the impact of transverse seismic wave is more obvious in soft soil, which often causes damage to the ground and ground facilities.

2) Social context destruction

In the process of rapid economic and social development, there are some social conflicts posed a potential threat to service facilities in urban communities. When failed to previously prevent or timely resolve these conflicts, Some malicious damages behavior maybe happen, by destroying service facilities to achieve the objective of disrupted normal social order.

3) Improper use of consumer

For lack of safety awareness, some resident's improper use of facilities causes accidents, resulting in public facilities parts. Some residents or renovators the community refuel gas pipelines, seal gas valves, which cause explosion accidents and damage the public parts of the facilities.

4) Third party construction activities

Ground subsidence caused by building construction outside the community, resulting in rupture of pipeline facilities in the community.

\subsection{Hazard-Affected Carriers Relevant Factors}

1) Unreasonable Community facilities planning and design

a) Evaluate incomplete or lack of foresight in preliminary planning and design

Due to the assessment of the community environment is not comprehensive, potential impact factors didn't been fully considered, or failed to prediction of development of disaster-pregnant environment, thus lead to the planning and design cannot meet the existing community situation. Such as the density of facilities in urban communities is too high, the safety distance between facilities is not enough, for economic and social development of the communities around expected is not accurate. 
Design problems are identified that impact constructability or that may impact facility performance.

b) Construction deviation from planning and design

Existing disaster prevention planning for most facilities has not developed a unified vulnerability and risk assessment standards and guidelines. Thus the operability of community comprehensive prevention planning is limited. Community pipeline as an example, geological disasters are not reasonably avoid, or pipeline does not comply with the security plan, cross or spacing distance was not up to standard.

c) Loose quality control

Quality supervision is the core of community facilities project supervision. Quality supervision is through the entire process from planning, design, construction to installation and acceptance. Various professional sub-projects and each stage is under the total supervision. There is not enough information supervision work for community facilities quantity. The disjoint responsibility between the responsibilities of the parties makes quality supervision lack of unified information, which reduces the effect of community facilities quality supervision.

d) Unreasonable facilities maintenance

At the macro level not only legal but also ethical aspect, the responsibility distribution of maintenance between the community developers, property management companies, and day-to-day maintenance units is ambiguous in China. Lack of effective theoretical assessment foundation to check the quality, leading to daily maintenance and quality cannot be assured.

\section{Governance Measures Based on the Overall Perspective}

The holistic perspective here refers to the diversity of the governance body and the whole life cycle of the formation of community facilities, which aims to the maintenance, improvement and adaptation of facilities in community to support social government. In this paper, the multi-subjects governance in community facilities affairs is viewed as necessary. Integrating multi-subjects into community facilities management and delivery processes will greatly improve the facilities safety use and the benefits to the community residents. The activities of multi-agent governance infiltrate into various community facilities safety governance measures, not only structural but also non-structural measures, through the whole life cycle of the formation of community facilities. The structural and non-structural measures are two aspects of disaster prevention and mitigation. Social diversity participation is an important resource base of community disaster prevention. In this field, the government guides and coordinates the integration of various resources, to guide and support disaster prevention community planning from the macro level, and to provide resources and information assistance. The community public and groups are the most important force to participate in and promote disaster prevention planning, construction, operation 
and maintenance for community facilities.

\subsection{Structural Measures}

Structural measures refer to the use of various disaster prevention and mitigation works to achieve the risk of disaster prevention and losses reduction, which are basic methods to upgrade the community facilities resistance against disturbance.

a) Strengthening scientific planning

The investigation of exploration for community facilities must be in-depth, and the community geological and environmental conditions should be fully considered. The planning and design must be scientific and conform to the provisions of safe production.

b) Improve construction quality

The construction unit must meet the requirements of the construction qualification of the community facilities project, and ensure the safety construction, regulate the site management, check the potential dangers and make contingency plans. The monitoring unit must be careful and responsible, with a rigorous attitude and strict standards for quality control. For new community facilities, we should strengthen the quality supervision of the construction process based on related laws and regulations.

c) Enhance community infrastructure health assessment

Health state evaluation is must. It can be used as a method to determine the community facilities operation reliability and safety state. The evaluation result can be used to guide the scientific community service facilities operation, maintenance and repair work. By setting up the maintenance evaluation system of urban community infrastructure, the maintenance evaluation findings can be released to the public in a timely manner, and make public supervision easy to be implemented. For existing community facilities, we must strengthen regular testing and maintenance.

\subsection{Non-Structural Measures}

Community facilities are often built according to established defense standards. Generally speaking, defense standards are limited by the cognition of disasters mechanism, investment quota, etc. It is difficult to avoid disasters that exceed the construction defense standard, so that non-structural measures is very important in this context.

a) The establishment of community emergency rescue team and linkage Mechanism

It's a must to set up community disaster prevention volunteer team and the establishment of community emergency rescue linkage Mechanism. Community disaster prevention volunteer teams are generally staffed from community workers, community residents, and units within the community. They can play role in for disaster prevention construction in the community. Once a disaster 
occurs, they can refer human, material and technical support in a community relief effort during the early stages of a disaster.

b) Innovation community facilities maintenance fund management model

At present, the construction of public service facilities in the community includes two main types of investment: government investment (policy investment and public welfare investment) and private investment. Maintenance of community facilities needs a lot of money supply. With a growing amount of community facilities, it's difficult to effectively ease the financial troubles of existing facilities maintenance relying solely on government financial supply and property charges. So innovation community facilities maintenance fund management model is necessary. To encourage private investment involved in community infrastructure operation and maintenance management fees in areas by tax deduction and exemption policy.

c) Strengthen the Accountability of Community Facilities

To promote the transparency in information of planning, construction, operation and maintenance of public facilities in urban communities is a must. For this, to enhance public awareness of the community facilities accident, improve self-protection awareness. It's time for us to perfect planning and integration of infrastructure operation monitoring and maintenance responsibility and accountability mechanisms to realize comprehensive tracing responsibility of accident. For community facilities caused by external disturbance factors, the responsibility of planning, construction, operation and maintenance should be checked one by one. For natural inevitable disturbance factors, the government should implement economic relief. For facilities' accident caused by social situational factors and improper use, we should deal with it according to the law or regulation.

\section{References}

[1] Goetsch, H.A. (1967) Manual on Urban Planning-Chapter VI: Community Facilities Planning. Journal of the Urban Planning and Development Division, No. 3, 15-42.

[2] Tammo, M. and Nelson, M. (2012) A Critical Review of the Concept of Facilities Management in Community-Based Contexts. The 28th Annual ARCOM Conference, Edinburgh UK, 1379-1388.

[3] Yun, G.-H. and Ko, Y.-J. (2017) The Application Direction of Universal Design for Prevention of Safety Accidents of Internal Facilities of Community Bus. Journal of the Korea Entertainment Industry Association, No. 4, 271-284.

[4] Zhang, R.-X. (2015) Investigation on the Existence of Underground Pipeline Engineering Files in Residential Communities. Lantai World, No. s5, 60.

[5] Moon, S.D. and Ock, J.H. (2015) Improvement Plane of the Facilities Management Manual to Prevent Safety Accidents in School. J. Korean Soc. Hazard Mitig, No. 4, 13-22. https://doi.org/10.9798/KOSHAM.2015.15.4.13

[6] Li, H.J. (2014) Planning and Design Research about Public Service Facility System for the Comprehensive Pension Community-Take the Health Care Center of Caotang Temple in Xian for Example. Xi'an Architecture and Technology University, 
Xi'an.

[7] Wu, Z.Z. (2013) A Study on the Reform of Administration of Civil Elevator Safety in Tianjin. Tianjin University, Tianjin.

[8] Zhe, Z. (2010) Design and Implementation of Community Electronic Service Network Security Monitoring Platform. Northwestern University, Xi'an.

[9] Dong, K.W. (2014) Research on the Disaster-Prevention System Adaptation Strategies for Existing Urban High-Rise Community. Tianjin University, Tianjin.

[10] Ye, T. (2015) The Research and Implementation of the Infrastructure Management System of Intelligent Community. Beijing University of Posts and Telecommunications, Beijing.

[11] Jing, W. (2011) Discussion on the Management of Underground Pipelines in Residential Communities. Urban Construction Archives, No. 10, 31-32.

[12] Zhao, Y. (2012) Studies on the Management System of Elevators in Residential Communities of Tianjin. Tianjin University, Tianjin.

[13] Zhao, Y.T. (2013) Research on the Planning and. Application of the Disaster Resistant Community. Tsinghua University, Beijing.

[14] Kasim, R. (2011) Community-Based Facilities Management: Theory and Practice. Pejabat Penerbit, Universiti Tun Hussein Onn Malaysia.

[15] Tucker, M.P., Masuri, M.R. and Cotgrave, A.J. (2017) Critical Strategic Issues for the Integration of Facilities Management into the Development Process. Property Management, Accepted Version.

\section{Scientific Research Publishing}

Submit or recommend next manuscript to SCIRP and we will provide best service for you:

Accepting pre-submission inquiries through Email, Facebook, LinkedIn, Twitter, etc. A wide selection of journals (inclusive of 9 subjects, more than 200 journals)

Providing 24-hour high-quality service

User-friendly online submission system

Fair and swift peer-review system

Efficient typesetting and proofreading procedure

Display of the result of downloads and visits, as well as the number of cited articles

Maximum dissemination of your research work

Submit your manuscript at: http://papersubmission.scirp.org/

Or contactwjet@scirp.org 